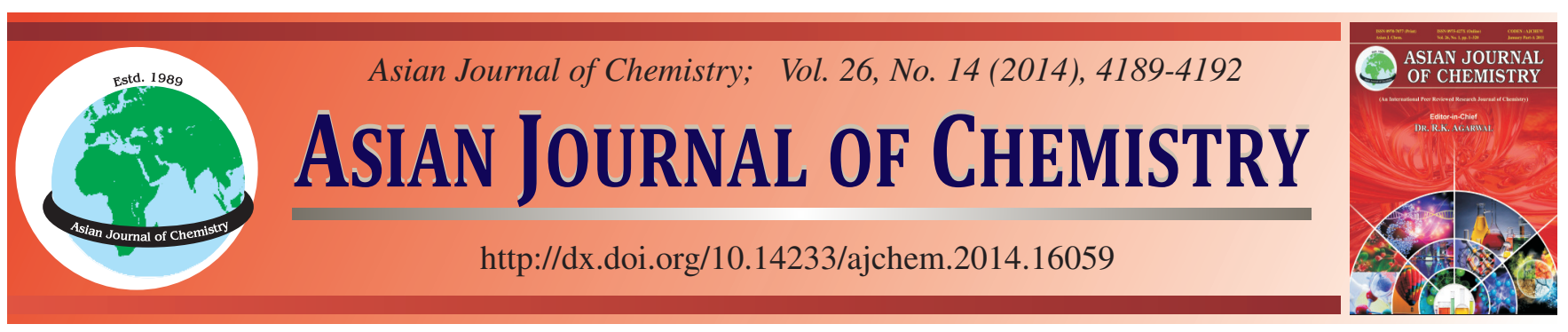

\title{
Evaluation of Chemical and Physico-Chemical Indicators of Water in Miedwie Lake (North-West Poland)
}

\author{
PIOTR DANISZEWSKI
}

Department of Invertebrate Zoology and Limnology, Faculty of Biology, University of Szczecin, 13 Waska Street, 71-415 Szczecin, Poland Corresponding author: E-mail: daniszewski73@gmail.com

This paper presents the evaluation of physico-chemical parameters of lake water in the Miedwie Lake based on the European Union Water Framework Directive. The research was carried out in the years 2008-2012, between April and October. From each of the three measuring stations located in the lakes included the study, two separate water samples were taken for chemical analysis. The studied lakes had $\mathrm{pH}$ values in the neutral range 7.61 to 7.88. According to the classification of the European Union Water Framework Directive, all lakes were classified as first class. By analyzing the average annual values, one can note that the $\mathrm{pH}, \mathrm{O}_{2 \text { diss }}$ and $\mathrm{NO}_{3}{ }^{-}$concentration showed a relatively small variation in all the investigated lakes. The total phosphorus concentration was $0.42-0.63 \mathrm{mgP} \mathrm{dm}^{-3}$. The concentrations of $\mathrm{PO}_{4}{ }^{3-}$ diss in the tested lake waters varied more significantly-corresponding to water quality classes ranging from III through IV. The concentrations saturation with $\mathrm{O}_{2}$ was 50.3-96.8 \%. In the case of nitrogen compounds, nitrates and nitrites values for these indicators fell into the I and II class in all the surveyed lakes. The indicator which proves high productivity of the lakes is the biochemical oxygen demand $\left(\mathrm{BOD}_{5}\right)$. The level of this indicator in the studied Lakes was at level III. The highest concentration of oxygen in the lake waters was found in the Lake Miedwie (about $8.9 \mathrm{mg} \mathrm{O}_{2} \mathrm{dm}^{-3}$ ).

Keywords: Water, Miedwie lake, Physico-chemical indicators, European Union Water Framework Directive.

\section{INTRODUCTION}

After the accession of Poland to the European Union is committed to the implementation of the European Union Water Framework Directive (2000/60/EC), whose main objective is to achieve good ecological status by 2015 and chemical surface waters $^{1-4}$.

Evaluation of the quality of the structure and functioning of aquatic ecosystems, by comparing the status of an existing undisturbed conditions expected in status (reference), is a requirement for monitoring and evaluation systems of classification by the European Directive 2000/60/EC, known as the European Union Water Framework Directive ${ }^{5,6}$.

Urbanization is the cause of many changes which are taking place in the environment, including those found in the catchment. With this in mind, it is an important issue to properly protect water reservoirs and also take action to counter the adverse effects of human activities on the natural environment, including water bodies. The ecological status of surface waters and groundwater is assessed on the basis of the ecological potential of the biological and physico-chemical and hydromorphological indicators.
This paper presents the evaluation of physico-chemical parameters of water in Miedwie Lake based on the European Union Water Framework Directive.

Lake Miedwie, the sixth largest lake in Poland, is located between Stargard Szczecinski and zczecin on the Pyrzycka Lowland. It is the largest freshwater reservoir in the Western Pomerania. It is $35 \mathrm{~km}^{2}$ large, $16.2 \mathrm{~km}$ long and $3.2 \mathrm{~km}$ wide. Its maximum depth is $43.8 \mathrm{~m}$. The capacity of the lake basin amounts to 681 million $\mathrm{m}^{3}$.

Miedwie is a deep, groove-like post-glacial lake, featuring an elongated, regular shape, without any larger breaks or incisions of its shoreline. There are no islands, clearly formulated peninsulas or bays. The southern part is slightly wider than the northern one. Nearly two thirds of Lake Miedwie constitutes the deepest cryptodepression in Poland. The deepest point of the lake bed lies $29.8 \mathrm{~m}$ below the sea level ${ }^{7,8}$.

The Plonia river flows through the lake. Furthermore, it is fed by the waters of: the Ostrowica, the Gowienica Miedwianska, the Miedwianka and numerous drainage ditches. The inflow of underground waters is estimated at $16 \%$. The terrain closest to Lake Miedwie is flat or rolling countryside used as fields, meadows and pastures. The area has been early 
and densely occupied with highly developed agriculture. Ten villages are located on the lake margins. In the summer time the reservoir is used extensively by tourists. Since 1976, the lake has been used by supply water for the city of Szczecin ${ }^{8}$.

\section{EXPERIMENTAL}

The research was carried out in the years 2008-2012, between April and October. From each of the three measuring stations located in the lakes included the study, two separate water samples were taken for chemical analysis.

\section{RESULTS AND DISCUSSION}

The results for the Miedwie Lake, along with the classification in accordance with the European Union Water Framework Directive are presented in Table-1.

The $\mathrm{pH}$ of the water in the lakes is influenced by the physico-chemical and biotic interactions of environmental factors $^{8-11}$

Among others, the degree of acidity directly affects life processes occurring in ecosystems. It is responsible for the correct uptake of nutrients by organisms. High alkalinity is beneficial for assimilation and therefore, the nitrogen and phosphorus compounds found in water are much more accessible than in an acid medium. Apart from high acidity, excessive alkalinity of natural waters ( $\mathrm{pH}$ above 9) also has a clearly detrimental impact on organisms ${ }^{12,13}$.

The studied lakes had $\mathrm{pH}$ values in the neutral range from 7.61 to 7.88 . According to the classification of the European
Union Water Framework Directive, all lakes were classified as first class.

The aquatic ecosystems of the studied lakes experienced loss on ignition and non-corresponding values of COD-Mn according to the estimates, which were based on the measurements of 'loss on drying' and 'residue on ignition' in accordance with the methodology set out by Macioszczyk ${ }^{14}$ and on the basis of COD-Mn results, which invariably matched III class water quality. In the lake waters tested, considerable levels of organic matter, including reducing agents, were maintained throughout the year. The reasons for this state of affairs should also be sought in the lake bed sediment, which is rich in organic matter ${ }^{15-17}$.

The most important elements involved in primary production are phosphorus and nitrogen. The presence of these substances determines the productivity of a water body, as well as its quality. One nutrient significantly affecting the quality of water is phosphorus. It is the primary factor which constrains the development of phytoplankton and thus affects massive algal blooms. It can occur in water bodies in the form of inorganic phosphorus as well as dissolved organic forms ${ }^{18,19}$.

Phosphates or the mineral forms of phosphorus, are best absorbed by organisms and play a huge role in the primary production of a reservoir. They are involved in the circulation of matter in any water body. Therefore, one should pay attention to phosphorus compounds in the demersal zone $e^{18-20}$.

Nitrogen occurs in the form of gas dissolved in the water, ammonium ions, nitrate and nitrite. In lakes, it is the main factor limiting the growth of organisms. The tests have

\begin{tabular}{|c|c|c|c|c|c|}
\hline \multicolumn{6}{|c|}{$\begin{array}{l}\text { TABLE-1 } \\
\text { ESULTS OF THE QUALITY OF SURFACE WATER OF LAKE MIEI } \\
\text { ALONG WITH THE CLASSIFICATION VALUES OF INDIC }\end{array}$} \\
\hline \multicolumn{6}{|c|}{2008 year } \\
\hline No & Water quality indices & Units & 17.04.2008 Spring & 24.07.2008 Summer & 15.10.2008 Autumn \\
\hline 1 & General Suspension & $\mathrm{mg} \mathrm{O}_{2} \mathrm{dm}^{-3}$ & 18.5 (II) & $20.6($ II $)$ & $21.2(\mathrm{II})$ \\
\hline 2 & $\mathrm{pH}$ & - & 7.78 (I) & 7.74 (I) & $7.76(\mathrm{I})$ \\
\hline 3 & COD-Mn & $\mathrm{mg} \mathrm{O}_{2} \mathrm{dm}^{-3}$ & 7.4 (III) & 8.7 (III) & 8.8 (III) \\
\hline 4 & $\mathrm{BOD}_{5}$ & $\mathrm{mg} \mathrm{O}_{2} \mathrm{dm}^{-3}$ & 3.5 (III) & 5.4 (III) & 4.5 (III) \\
\hline 5 & $\mathrm{O}_{2 \text { diss. }}$ & $\mathrm{mg} \mathrm{O}_{2} \mathrm{dm}^{-3}$ & 8.1 (I) & $8.3(\mathrm{I})$ & $7.6(\mathrm{I})$ \\
\hline 6 & $\mathrm{NO}_{3}-$ & $\mathrm{mg} \mathrm{N} \mathrm{dm}{ }^{-3}$ & 0.18 (I) & $0.25(\mathrm{I})$ & $0.21(\mathrm{I})$ \\
\hline 7 & $\mathrm{NO}_{2}^{-}$ & $\mathrm{mg} \mathrm{N} \mathrm{dm}^{-3}$ & 0.031 (II) & 0.036 (II) & 0.034 (II) \\
\hline 8 & $\mathrm{NH}_{4}^{+}$ & $\mathrm{mg} \mathrm{N} \mathrm{dm}{ }^{-3}$ & 0.51 (II) & 0.77 (II) & 0.66 (II) \\
\hline 9 & $\mathrm{PO}_{4}^{3-}$ diss. & $\mathrm{mg} \mathrm{PO}_{4} \mathrm{dm}^{-3}$ & 0.73 (IV) & 0.81 (IV) & 0.61 (III) \\
\hline 10 & $\mathrm{P}_{\text {tot. }}$ & $\mathrm{mg} \mathrm{P} \mathrm{dm}{ }^{-3}$ & 0.42 (III) & 0.58 (III) & 0.45 (III) \\
\hline 11 & Saturation with $\mathrm{O}_{2}$ & $\%$ & 63.8 & 87.4 & 50.7 \\
\hline 12 & Residue after ignition & $\mathrm{mg} \mathrm{dm}^{-3}$ & 174 & 198 & 169 \\
\hline \multicolumn{6}{|c|}{2009 year } \\
\hline No & Water quality indices & Units & 15.04.2009 Spring & 22.07.2009 Summer & 21.10.2009 Autumn \\
\hline 1 & General Suspension & $\mathrm{mg} \mathrm{O}_{2} \mathrm{dm}^{-3}$ & 19.3 (II) & 20.4 (II) & 19.8 (II) \\
\hline 2 & $\mathrm{pH}$ & - & 7.61 (I) & 7.78 (I) & 7.79 (I) \\
\hline 3 & COD-Mn & $\mathrm{mg} \mathrm{O}_{2} \mathrm{dm}^{-3}$ & 7.5 (III) & 8.5 (III) & 8.0 (III) \\
\hline 4 & $\mathrm{BOD}_{5}$ & $\mathrm{mg} \mathrm{O}_{2} \mathrm{dm}^{-3}$ & 4.4 (III) & 4.7 (III) & 3.9 (III) \\
\hline 5 & $\mathrm{O}_{2 \text { diss. }}$ & $\mathrm{mg} \mathrm{O}_{2} \mathrm{dm}^{-3}$ & 7.7 (I) & $8.4(\mathrm{I})$ & 8.1 (I) \\
\hline 6 & $\mathrm{NO}_{3}$ & $\mathrm{mg} \mathrm{N} \mathrm{dm}{ }^{-3}$ & 0.34 (I) & $0.41(\mathrm{I})$ & $0.38(\mathrm{I})$ \\
\hline 7 & $\mathrm{NO}_{2}^{-}$ & $\mathrm{mg} \mathrm{N} \mathrm{dm}{ }^{-3}$ & 0.036 (II) & 0.039 (II) & 0.035 (II) \\
\hline 8 & $\mathrm{NH}_{4}^{+}$ & $\mathrm{mg} \mathrm{N} \mathrm{dm}^{-3}$ & 0.60 (II) & 0.86 (II) & 0.72 (II) \\
\hline 9 & $\mathrm{PO}_{4}^{3-}$ diss. & $\mathrm{mg} \mathrm{PO}_{4} \mathrm{dm}^{-3}$ & 0.78 (IV) & 0.73 (IV) & 0.57 (III) \\
\hline 10 & $\mathrm{P}_{\text {tot. }}$ & $\mathrm{mg} \mathrm{P} \mathrm{dm} \mathrm{dm}^{-3}$ & 0.44 (III) & 0.52 (III) & 0.42 (III) \\
\hline 11 & Saturation with $\mathrm{O}_{2}$ & $\%$ & 59.2 & 94.8 & 53.7 \\
\hline 12 & Residue after ignition & $\mathrm{mg} \mathrm{dm}{ }^{-3}$ & 169 & 206 & 181 \\
\hline
\end{tabular}




\begin{tabular}{|c|c|c|c|c|c|}
\hline \multicolumn{6}{|c|}{2010 year } \\
\hline No & Water quality indices & Units & 21.04.2010 Spring & 14.07.2010 Summer & 20.10.2010 Autumn \\
\hline 1 & General Suspension & $\mathrm{mg} \mathrm{O}_{2} \mathrm{dm}^{-3}$ & 18.9 (II) & 21.9 (II) & $20.6(\mathrm{II})$ \\
\hline 2 & $\mathrm{pH}$ & - & 7.62 (I) & 7.74 (I) & 7.78 (I) \\
\hline 3 & COD-Mn & $\mathrm{mg} \mathrm{O}_{2} \mathrm{dm}^{-3}$ & 7.3 (III) & 7.8 (III) & 7.3 (III) \\
\hline 4 & $\mathrm{BOD}_{5}$ & $\mathrm{mg} \mathrm{O}_{2} \mathrm{dm}^{-3}$ & 4.7 (III) & 5.1 (III) & 4.8 (III) \\
\hline 5 & $\mathrm{O}_{2 \text { diss. }}$ & $\mathrm{mg} \mathrm{O}_{2} \mathrm{dm}^{-3}$ & $7.5(\mathrm{I})$ & 8.9 (I) & $8.2(\mathrm{I})$ \\
\hline 6 & $\mathrm{NO}_{3}$ & $\mathrm{mg} \mathrm{N} \mathrm{dm} \mathrm{m}^{-3}$ & $0.34(\mathrm{I})$ & $0.31(\mathrm{I})$ & $0.46(\mathrm{I})$ \\
\hline 7 & $\mathrm{NO}_{2}-$ & $\mathrm{mg} \mathrm{N} \mathrm{dm}{ }^{-3}$ & 0.031 (II) & 0.035 (II) & 0.037 (II) \\
\hline 8 & $\mathrm{NH}_{4}^{+}$ & $\mathrm{mg} \mathrm{N} \mathrm{dm}{ }^{-3}$ & 0.71 (II) & 0.86 (II) & 0.63 (II) \\
\hline 9 & $\mathrm{PO}_{4}^{3-}$ diss. & $\mathrm{mg} \mathrm{PO}_{4} \mathrm{dm}^{-3}$ & 0.57 (III) & 0.52 (III) & 0.69 (III) \\
\hline 10 & $P_{\text {tot. }}$ & $\mathrm{mg} \mathrm{P} \mathrm{dm}-3$ & 0.43 (III) & 0.61 (III) & 0.47 (III) \\
\hline 11 & Saturation with $\mathrm{O}_{2}$ & $\%$ & 68.2 & 87.6 & 50.3 \\
\hline 12 & Residue after ignition & $\mathrm{mg} \mathrm{dm}{ }^{-3}$ & 174 & 218 & 187 \\
\hline \multicolumn{6}{|c|}{2011 year } \\
\hline No & Water quality indices & Units & 20.04.2011 Spring & 20.07.2011 Summer & 19.10.2011 Autumn \\
\hline 1 & General Suspension & $\mathrm{mg} \mathrm{O}_{2} \mathrm{dm}^{-3}$ & 20.4 (II) & 22.5 (II) & $21.2(\mathrm{II})$ \\
\hline 2 & $\mathrm{pH}$ & - & 7.65 (I) & 7.79 (I) & $7.72(\mathrm{I})$ \\
\hline 3 & COD-Mn & $\mathrm{mg} \mathrm{O}_{2} \mathrm{dm}^{-3}$ & 7.6 (III) & 8.1 (III) & 6.9 (III) \\
\hline 4 & $\mathrm{BOD}_{5}$ & $\mathrm{mg} \mathrm{O}_{2} \mathrm{dm}^{-3}$ & 4.5 (III) & 4.9 (III) & 4.8 (III) \\
\hline 5 & $\mathrm{O}_{2 \text { diss. }}$ & $\mathrm{mg} \mathrm{O}_{2} \mathrm{dm}^{-3}$ & 8.1 (I) & 8.0 (I) & $7.3(\mathrm{I})$ \\
\hline 6 & $\mathrm{NO}_{3}$ & $\mathrm{mg} \mathrm{N} \mathrm{dm}{ }^{-3}$ & $0.41(\mathrm{I})$ & $0.26(\mathrm{I})$ & 0.21 (I) \\
\hline 7 & $\mathrm{NO}_{2}^{-}$ & $\mathrm{mg} \mathrm{N} \mathrm{dm} \mathrm{m}^{-3}$ & 0.034 (II) & 0.022 (II) & 0.047 (II) \\
\hline 8 & $\mathrm{NH}_{4}^{+}$ & $\mathrm{mg} \mathrm{N} \mathrm{dm}{ }^{-3}$ & 0.91 (II) & 0.76 (II) & 0.83 (II) \\
\hline 9 & $\mathrm{PO}_{4}^{3-}$ diss. & $\mathrm{mg} \mathrm{PO}_{4} \mathrm{dm}^{-3}$ & 0.46 (III) & 0.72 (IV) & 0.53 III) \\
\hline 10 & $P_{\text {tot. }}$ & $\mathrm{mg} \mathrm{P} \mathrm{dm}-3$ & 0.48 (III) & 0.63 (III) & 0.51 (III) \\
\hline 11 & Saturation with $\mathrm{O}_{2}$ & $\%$ & 65.8 & 79.5 & 54.6 \\
\hline 12 & Residue after ignition & $\mathrm{mg} \mathrm{dm} \mathrm{m}^{-3}$ & 184 & 217 & 170 \\
\hline \multicolumn{6}{|c|}{2012 year } \\
\hline No & Water quality indices & Units & 18.04.2012 Spring & 18.07.2012 Summer & 27.09.2012 Autumn \\
\hline 1 & General Suspension & $\mathrm{mg} \mathrm{O}_{2} \mathrm{dm}^{-3}$ & 24.1 (II) & 24.3 (II) & $18.9(\mathrm{II})$ \\
\hline 2 & $\mathrm{pH}$ & - & 7.74 (I) & 7.88 (I) & $7.81(\mathrm{I})$ \\
\hline 3 & COD-Mn & $\mathrm{mg} \mathrm{O}_{2} \mathrm{dm}^{-3}$ & 8.5 (III) & 8.6 (III) & 7.8 (III) \\
\hline 4 & $\mathrm{BOD}_{5}$ & $\mathrm{mg} \mathrm{O}_{2} \mathrm{dm}^{-3}$ & 4.2 (III) & 5.6 (III) & 4.4 (III) \\
\hline 5 & $\mathrm{O}_{2 \text { diss. }}$ & $\mathrm{mg} \mathrm{O}_{2} \mathrm{dm}^{-3}$ & 7.7 (I) & $8.3(\mathrm{I})$ & 8.2 (I) \\
\hline 6 & $\mathrm{NO}_{3}$ & $\mathrm{mg} \mathrm{N} \mathrm{dm}{ }^{-3}$ & $0.48(\mathrm{I})$ & $0.51(\mathrm{I})$ & $0.39(\mathrm{I})$ \\
\hline 7 & $\mathrm{NO}_{2}^{-}$ & $\mathrm{mg} \mathrm{N} \mathrm{dm}{ }^{-3}$ & 0.034 (II) & 0.036 (II) & 0.031 (II) \\
\hline 8 & $\mathrm{NH}_{4}^{+}$ & $\mathrm{mg} \mathrm{N} \mathrm{dm}{ }^{-3}$ & 0.67 (II) & 0.79 (II) & 0.54 (II) \\
\hline 9 & $\mathrm{PO}_{4}{ }^{3-}$ diss. & $\mathrm{mg} \mathrm{PO}_{4} \mathrm{dm}^{-3}$ & 0.45 (III) & 0.57 (III) & 0.46 (III) \\
\hline 10 & $\mathrm{P}_{\text {tot. }}$ & $\mathrm{mg} \mathrm{P} \mathrm{dm} \mathrm{dm}^{-3}$ & 0.42 (III) & 0.60 (III) & 0.48 (III) \\
\hline 11 & Saturation with $\mathrm{O}_{2}$ & $\%$ & 72.5 & 96.8 & 58.1 \\
\hline 12 & Residue after ignition & $\mathrm{mg} \mathrm{dm} \mathrm{m}^{-3}$ & 191 & 205 & 185 \\
\hline
\end{tabular}

demonstrated that water quality in the lakes with regard to the tested indicators varied. By analyzing the average annual values, one can note that the $\mathrm{pH}, \mathrm{O}_{2 \text { diss }}$ and $\mathrm{NO}_{3}{ }^{-}$concentration showed a relatively small variation in all the investigated lakes.

General suspension in Miedwie Lake, fell into the II class: The $\mathrm{P}_{\text {tot. }}$ concentrations in the surface layer of the lakes was little differentiated, reaching the levels appropriate for the III quality class according to the classification of the EU Water Framework Directive. The total phosphorus concentration was $0.42-0.63 \mathrm{mgP} \mathrm{dm}^{-3}$. The highest concentration of total phosphorus was recorded in Lake Miedwie-summer 2011 (about $0.63 \mathrm{mgP} \mathrm{dm}^{-3}$ ).

The concentrations of $\mathrm{PO}_{4}{ }^{3-}$ diss in the tested lake waters varied more significantly-corresponding to water quality classes ranging from III through IV. An upswing in the concentration of phosphorus compounds in a lake may indicate a decreased amount of oxygen in the benthic waters and changes in their redox status leading to releasing phosphorus compounds accumulated in the bed sediment ${ }^{15}$.

The concentrations saturation with $\mathrm{O}_{2}$ was 50.3-96.8 \%. The highest concentration of saturation with $\mathrm{O}_{2}$ was recorded in Lake Miedwie-summer 2012. In the case of nitrogen compounds, nitrates and nitrites values for these indicators fell into the I and II class in all the surveyed lakes in accordance with the classification of the European Union Water Framework Directive.

The indicator which proves high productivity of the lakes is the biochemical oxygen demand $\left(\mathrm{BOD}_{5}\right)$. The level of this indicator in the studied Lakes was at level III. The highest concentration of biochemical oxygen demand was recorded in Lake Miedwie-summer 2012 (about $5.6 \mathrm{mg} \mathrm{O}_{2} \mathrm{dm}^{-3}$ ).

The highest concentration of oxygen in the lake waters was found in the Lake Miedwie (about $8.9 \mathrm{mg} \mathrm{O}_{2} \mathrm{dm}^{-3}$ ). In the remaining lake oxygen levels were similar (still in I class). 


\section{REFERENCES}

1. P. Daniszewski, Int. Lett. Chem., Phys. Astron., 1, 6 (2012).

2. P. Daniszewski, Int. Lett. Chem., Phys. Astron., 2, 35 (2012).

3. A. Kownacki, H. Soszka, D. Kudelska, T. Flejtuch, in eds. W. Geller, et al. Bioassessment of Polish Rivers Based on Macroinvertebrates, In: 11th Magdeburg Seminar on Waters in Central and Eastern Europe: Assessment, Protection, Management, Proceedings of the International Conference, 18-22 October, 2004 at UFZ-Bericht, 18, pp. 250251 (2004).

4. G. Van Urk and B. de Vaate, in eds.: R. Kinzelbach and G. Friedrich, Ecological Studies in the Lower Rhine in The Netherlands; In: Biologie des Rheins. Limnologie Aktuell., vol. 1, pp. 131-145 (1990).

5. Directive 2000/60/EC of the European Parliament and of the Council of 23 October 2000 Establishing a Framework for Community Action in the Field of Water Policy, Off. J. Eur. Commun., L327, 22 December 2000.

6. Z. Kajak, Hydrobiology-Limnology, Inland Water Ecosystems, PWN, Warsaw, pp. 355 (1998).

7. J. Janczak, Atlas Polish Lakes, pp. 98-99 (1996).

8. E. Sroka, Annal. Univ. Mariae Curie-Sklodowska-Lublin-Polonia, 63 81 (2007).
9. E. Bajkiewicz-Grabowska, J. Hydrol. Sci., 8, 63 (1981)

10. E. Bécares, Limnetica, 25, 143 (2006).

11. F. Garcia-Criado, A. Tomé, F.J. Vega and C. Antolin, Hydrobiologia, 394, 209 (1999).

12. J. Trojanowski, J. Antonowicz, M. Król and J. Bruski, Annal. Polish Chem. Soc., 1, 131 (2001).

13. J. Trojanowski and J. Bruski, Baltic Coastal Zone, 4, 53 (2000).

14. A. Macioszczyk, Hydrochemistry, Warsaw, pp. 475 (1987).

15. J.F. Wright, D. Moss, P.D. Armitage and M.T. Furs, Freshwat. Biol., 14, 221 (1984).

16. B. Zdanowski, Ekol. Pol., 31, 287 (1983).

17. M. Søndergaard, K.D. Wolter and W. Ripl, in eds.: M.R. Perow and A.J. Davy, Chemical Treatment of Water and Sediments with Special Reference to Lakes; In: Handbook of Ecological Restoration, Cambridge University Press, Cambridge, pp. 184-205 (2002).

18. W. Lampert and U. Sommer, Ecology of Inland Waters, Scientific Publishing PWN, Warsaw pp. 415 (2001).

19. J. Kubiak, Acta Sci. Pol. Piscaria, 2, 141 (2003).

20. T. Fleituch, H. Soszka, D. Kudelska and A. Kownacki, Arch. Hydrobiol., Suppl.141/3, 225 (2002). 